\title{
Cardioprotection against experimental myocardial ischemic injury using cornin
}

\author{
Y. Xu, Y. Xu, H. Luan, Y. Jiang, X. Tian and S. Zhang \\ School of Pharmaceutical Sciences, Binzhou Medical University, Yantai, China
}

\begin{abstract}
Phosphorylated-cyclic adenosine monophosphate response element-binding protein (Phospho-CREB) has an important role in the pathogenesis of myocardial ischemia. We isolated the iridoid glycoside cornin from the fruit of Verbena officinalis $\mathrm{L}$, investigated its effects against myocardial ischemia and reperfusion $(\mathrm{l} / \mathrm{R})$ injury in vivo, and elucidated its potential mechanism in vitro. Effects of cornin on cell viability, as well as expression of phospho-CREB and phospho-Akt in hypoxic H9c2 cells in vitro, and myocardial I/R injury in vivo, were investigated. Cornin attenuated hypoxia-induced cytotoxicity significantly in H9c2 cells in a concentrationdependent manner. Treatment of $\mathrm{H} 9 \mathrm{c} 2$ cells with cornin $(10 \mu \mathrm{M})$ blocked the reduction of expression of phospho-CREB and phospho-Akt in a hypoxic condition. Treatment of rats with cornin $(30 \mathrm{mg} / \mathrm{kg}, \mathrm{iv})$ protected them from myocardial I/R injury as indicated by a decrease in infarct volume, improvement in hemodynamics, and reduction of severity of myocardial damage. Cornin treatment also attenuated the reduction of expression of phospho-CREB and phospho-Akt in ischemic myocardial tissue. These data suggest that cornin exerts protective effects due to an increase in expression of phospho-CREB and phospho-Akt.
\end{abstract}

Key words: Cornin; Myocardial ischemia and reperfusion; CREB; Akt; Hypoxia

\section{Introduction}

Primary myocardial ischemia-reperfusion $(\mathrm{I} / \mathrm{R})$ therapies such as percutaneous coronary intervention and thrombolysis are the standard of care for acute coronary syndromes. Prompt restoration of blood flow to the ischemic myocardium limits infarct size and the risk of death. Paradoxically, the return of blood flow can also result in additional cardiac damage and complications such as reperfusion injury. Effective therapies to reduce or prevent reperfusion injury have proved elusive. Despite improved understanding of the pathophysiology of reperfusion injury and encouraging preclinical trials using multiple agents, most clinical trials focusing on prevention of reperfusion injury have been disappointing $(1,2)$. Despite these problems, adjunctive therapies to limit reperfusion injury remain an active area of investigation.

Cyclic adenosine monophosphate response elementbinding protein (CREB) is a cellular transcription factor that binds to certain DNA sequences called cyclic adenosine monophosphate response elements and influences transcription of downstream genes. Phosphorylated-CREB (Phospho-CREB) is an activated form of CREB involved in myocardial protection against I/R-related injury $(3,4)$. Increased levels of phospho-CREB in myocardial tissue could attenuate I/R-related injury (5). Protein kinase B, also known as Akt, is a serine/threonine-specific protein kinase that plays a key part in multiple cellular processes: glucose metabolism, apoptosis and transcription. Akt promotes cell survival by stimulating expression of cellular genes via the CREB nuclear transduction pathway (6).

Cornin is an iridoid glycoside isolated from the fruit of Verbena officinalis L. It has protective actions against cerebral ischemia injury (7) and induces angiogenesis in vitro (8). We wished to investigate the effects of cornin in a rat model of myocardial $\mathrm{I} / \mathrm{R}$ as well as its potential cardioprotective mechanism in cultured H9c2 cells and intact rats.

\section{Material and Methods}

\section{Material}

Cornin (purity $>99.0 \%$, CAS number, 548-37-8; molecular formula, $\mathrm{C}_{17} \mathrm{H}_{24} \mathrm{O}_{10}$; molecular weight, 388.37) was dissolved in sterile physiologic $(0.9 \%)$ saline to make a stock solution. Dilutions were prepared according to different administration doses. Troponin T (cTnT) enzyme-linked immunosorbent assay kits were purchased from Maisha Biology (China). Polyclonal rabbit anti-mouse phosphoCREB and phospho-Akt antibodies were purchased from Biosynthesis Biotechnology (China). 


\section{Animals}

All experimental designs and procedures were conducted in accordance with the Animal Care Guidelines of the Animal Experimental Committee of Binzhou Medical University (China; authorization number, BYLY 2015-74).

Thirty adult male Sprague-Dawley rats $(270-300 \mathrm{~g})$ were housed individually under constant temperature (22 $\pm 2^{\circ} \mathrm{C}$ ) and humidity with a 12-h light/dark cycle. They had free access to rodent food and water.

\section{Cell culture}

H9c2 cells (clonal line derived from embryonic rat hearts) were purchased from American Type Culture Collection (USA). Cells were cultured in Dulbecco's modified Eagle's medium (DMEM) containing D-glucose (4.5 g/L), 20\% fetal bovine serum (FBS), 10,000 U/L penicillin, and $10 \mathrm{mg} / \mathrm{L}$ streptomycin using standard methods in an incubator with an atmosphere of $5 \% \mathrm{CO}_{2}$ at $37^{\circ} \mathrm{C}$. The medium was changed every 2 days. Upon reaching confluence, cells were subcultured by detachment with $0.25 \%$ trypsin-EDTA solution (Sigma-Aldrich, USA), re-seeded onto new plates at a ratio of $1: 5$, and incubated in DMEM containing $2 \%$ FBS. Cells were maintained at $37^{\circ} \mathrm{C}$ in a humidified incubator in an atmosphere of $5 \% \mathrm{CO}_{2} / 95 \%$ air.

\section{Hypoxia model in vitro}

To mimic hypoxia injury in vitro, cells were incubated in a hypoxic solution for $6 \mathrm{~h}$. The hypoxic solution (9) contained $0.9 \mathrm{mM} \mathrm{NaH}_{2} \mathrm{PO}_{4}, 6.0 \mathrm{mM} \mathrm{NaHCO}, 1.0 \mathrm{mM}$ $\mathrm{CaCl}_{2}, 1.2 \mathrm{mM} \mathrm{MgSO}_{4}, 40 \mathrm{mM}$ natrum lacticum, $20 \mathrm{mM}$ HEPES, $98.5 \mathrm{mM} \mathrm{NaCl}, 10.0 \mathrm{mM} \mathrm{KCl}$ (pH adjusted to 6.8) and was bubbled with $\mathrm{N}_{2}$ for 30 min before application. The partial pressure of oxygen of the hypoxic solution was adjusted to $\leqslant 4.0 \mathrm{kPa}$. Hypoxia was elicited by placing the plates of cultured cardiomyocytes in a hypoxic incubator (Kendro, Germany) while oxygen was adjusted to $1.0 \%$ and $\mathrm{CO}_{2}$ to $5.0 \%$. Before hypoxia, cells were pretreated with cornin $(1,3,10$, and $30 \mu \mathrm{M})$ for $24 \mathrm{~h}$. Normal culture (DMEM containing 2\% FBS under an atmosphere of $20 \%$ oxygen and $5 \% \mathrm{CO}_{2}$ ) served as a negative control group, and the hypoxic culture solution served as the hypoxia group.

\section{Cell viability assays}

Cell viability was determined by the 3-(4,5-dimethylthiazol-2-yl)-2,5-diphenyltetrazolium bromide (MTT) assay. Cells were seeded at $8 \times 10^{3}$ cells/well in 96-well cell culture plates. After exposure to hypoxia, $20 \mu \mathrm{L}$ of MTT solution (5 $\mathrm{mg} / \mathrm{mL}$ ) was added into each well and the final concentration made up to $0.5 \mathrm{mg} / \mathrm{mL}$. Plates were incubated for an additional $2 \mathrm{~h}$ and the absorbance at $490 \mathrm{~nm}$ measured in a microplate reader. Percent viability was defined as the relative absorbance of treated cells compared with untreated control cells.

\section{Western blotting of hypoxic $\mathrm{H} 9 \mathrm{c} 2$ cell}

Before hypoxia, cells were pretreated with cornin $(1,3,10$, and $30 \mu \mathrm{M}$ ) for $24 \mathrm{~h}$. Then, they were incubated in hypoxic solution for $6 \mathrm{~h}$, washed twice with ice-cold phosphatebuffered saline and lysed in NP40 lysis buffer (50 mM Tris, pH 7.4, $250 \mathrm{mM} \mathrm{NaCl}, 5 \mathrm{mM}$ EDTA, $50 \mathrm{mM} \mathrm{NaF}, 1 \mathrm{mM} \mathrm{Na}_{3} \mathrm{VO}_{4}$, $1 \% \mathrm{NP}-40$ and $0.02 \% \mathrm{NaN}_{3}$; Biosource, USA) supplemented with $1 \mathrm{mM}$ phenylmethanesulfonyl fluoride and $1 \times$ protease inhibitor cocktail (Sigma-Aldrich). Equal amounts of cell protein $(40 \mu \mathrm{g})$ were separated by sodium dodecyl sulfatepolyacrylamide gel electrophoresis (SDS-PAGE) and analyzed by Western blotting using specific antibodies against phospho-CREB, phospho-Akt and $\beta$-actin (loading control). Absorbance of the bands was quantified with Gel Doc 2000 (Bio-Rad, USA). Data were normalized against those of the corresponding bands of proliferating cell nuclear antigen. Results were reported as fold-increase over control.

\section{Induction of myocardial I/R injury}

Myocardial I/R procedures were induced according to a procedure described previously (10). Briefly, rats were anesthetized with ketamine $100 \mathrm{mg} / \mathrm{kg}(\mathrm{im})$ and xylazine $10 \mathrm{mg} / \mathrm{kg}(\mathrm{im})$ and ventilated with room air using a rodent respirator. The chest was opened by middle thoracotomy. After pericardiotomy, a 4-0 black silk ligature was placed under the left anterior descending artery (LAD). The ends of the tie were threaded through a small vinyl tube to form a "snare" for reversible occlusion of the LAD. After $30 \mathrm{~min}$ of ischemia, the myocardium was re-perfused by loosening the snare for $24 \mathrm{~h}$.

A pilot study was conducted with four doses of cornin $(7.5,15,30$, and $60 \mathrm{mg} / \mathrm{kg})$ to determine dose dependency in acute I/R-treated rats. Cornin post-treatment (15, 30, and $60 \mathrm{mg} / \mathrm{kg})$ significantly $(P<0.05)$ lowered elevated levels of creatine kinase-MB (CK-MB) and cardiac troponin (cTnT) in the serum of acute I/R-induced rats after $240 \mathrm{~min}$. Hence, cornin at $30 \mathrm{mg} / \mathrm{kg}$ was chosen for the present study.

Ninety rats were divided into three groups: i) nonmyocardial I/R (the silk suture crossed without ligation and I/R was not incurred); ii) I/R rats received saline only; iii) $\mathrm{l} / \mathrm{R}$ rats received cornin $(30 \mathrm{mg} / \mathrm{kg}, \mathrm{iv})$.

Rats in each group were divided into three subgroups of 10 and received drug treatment (iv) at the indicated dose after reperfusion for $5 \mathrm{~min}$. Cornin was dissolved in sterile saline to make stock solutions and appropriate dilutions according to the doses required. The first subgroup of animals was used for evaluation of hemodynamics, infarct size, as well as serum levels of CK-MB and cTnT. The second subgroup was used for histopathologic and Western-blotting analyses. The third subgroup was used for evaluation of hemodynamics at day-14.

\section{Evaluation of hemodynamics}

Rats were anesthetized with ketamine $(100 \mathrm{mg} / \mathrm{kg}, \mathrm{im})$ and xylazine $(10 \mathrm{mg} / \mathrm{kg}, \mathrm{im}) 24 \mathrm{~h}$ after l/R. A catheter-tip manometer (Millar Instruments, USA) was inserted into the 
left ventricular cavity via the right common carotid artery. Pressure was transduced and amplified by a pressure transducer. Left ventricular systolic pressure (LVSP) and maximal rate of rise of left ventricular pressure ( $\pm \mathrm{dp} / \mathrm{dtmax}$ ) were recorded and programmed using a biotic signal collection and processing system (Biopic, USA).

\section{Determination of serum levels of CK-MB and cTnT}

Blood samples were collected $24 \mathrm{~h}$ after I/R. Serum levels of CK-MB and CTnT were measured using enzymelinked immunosorbent assay kits.

\section{Analyses of myocardial infarction}

Acute myocardial infarction was determined according to a method described previously (11). The non-ischemic area, area at risk, and infarct area of each tissue slice were separated, weighed, and calculated as a percentage of corresponding area multiplied by slice weight.

\section{Western blotting of myocardial tissue}

Heart samples (area at risk) were taken $24 \mathrm{~h}$ after I/R and suspended in a buffer containing $10 \mathrm{mM}$ Tris, $\mathrm{pH}$ 7.5,1.5 $\mathrm{mM} \mathrm{MgCl}_{2}, 10 \mathrm{mM} \mathrm{KCl}$, and $0.1 \%$ Triton X-100, and lysed by homogenization. Nuclei were recovered by microcentrifugation at $2000 \mathrm{~g}$ for $5 \mathrm{~min}$ at $4^{\circ} \mathrm{C}$. Supernatants were collected and stored at $-80^{\circ} \mathrm{C}$ for Western blotting. Nuclear proteins were extracted at $4^{\circ} \mathrm{C}$ by resuspending the nuclei pellet gently in buffer containing $20 \mathrm{mM}$ Tris, $\mathrm{pH} 7.5,20 \%$ glycerol, $1.5 \mathrm{mM} \mathrm{MgCl}_{2}, 420 \mathrm{mM}$ $\mathrm{NaCl}, 0.2 \mathrm{mM}$ EDTA, and $0.1 \%$ Triton $\mathrm{X}-100$, followed by 1 -h incubation with occasional vortex-mixing at $4^{\circ} \mathrm{C}$. After microcentrifugation at $5250 \mathrm{~g}$ for $15 \mathrm{~min}$ at $4^{\circ} \mathrm{C}$, supernatants were collected. Protein concentrations of extracts were measured by bicinchoninic acid assay. Equal amounts of cell protein $(50 \mu \mathrm{g})$ were separated by SDSPAGE and analyzed by Western blotting using specific antibodies against phospho-CREB, phospho-Akt and $\beta$-actin. Absorbance of bands was quantified with $\mathrm{Gel}$ Doc 2000 (Bio-Rad). Data were normalized against those of corresponding $\beta$-actin bands. Results were reported as fold-increase over the sham group.

\section{Histopathologic examination of myocardial tissue $24 \mathrm{~h}$ after I/R}

Hearts were fixed in $10 \%$ formalin and embedded in paraffin. Sections were stained with hematoxylin \& eosin after fixation. Pathological scores were determined by an investigator blinded to the experimental design. Morphological criteria were used to assess histopathological damage: 0 , no damage; 1 (mild), interstitial edema and focal necrosis; 2 (moderate), diffuse myocardial cell swelling and necrosis; 3 (severe), necrosis with contraction bands, neutrophil infiltration, and compression of capillaries; 4 (very severe), widespread necrosis with contraction bands, neutrophil infiltration, capillary compression and hemorrhage.

\section{Statistical analyses}

Histopathological scores between groups were compared using the sum of ranks test. Quantitative data from experiments are reported as means $\pm S D$. Significance was determined by one-way analysis of ANOVA followed by Dunnett's test. $\mathrm{P}<0.05$ was considered significant.

\section{Results}

\section{Cornin attenuated hypoxia-induced cytotoxicity}

Results of the cell viability assay are shown in Figure 1. After exposure to hypoxia for $6 \mathrm{~h}$, only $50.3 \pm 5.7 \%$ viable cells remained as compared with control cells. Cornin $(1,3,10$, and $30 \mu \mathrm{M})$ prevented cells from incurring hypoxia-induced damage in a concentration-dependent manner, and restored cell survival to $56.0 \pm 6.4,60.3 \pm 5.8$, $64.4 \pm 7.0$, and $68.7 \pm 7.3 \%$, respectively (Figure 1).

To clarify the mechanism of action of cornin on hypoxia-induced cytotoxicity, a selective inhibitor of CREB $(\mathrm{C} 646,1 \mu \mathrm{M})$ or Akt (MK2206, $1 \mu \mathrm{M})$ was used. We found that pretreatment of $\mathrm{H} 9 \mathrm{c} 2$ cells with cornin plus $\mathrm{C} 646$ $(1 \mu \mathrm{M})$ or MK2206 $(1 \mu \mathrm{M})$ for $120 \mathrm{~min}$ did not decrease hypoxia-induced cellular damage (Figure $2 \mathrm{~A}$ ).

\section{Cornin attenuated the reduction in expression of phospho-CREB and phospho-Akt during hypoxia}

We investigated the effect of cornin on hypoxia-induced reduction of expression of phospho-CREB and phospho-Akt in $\mathrm{H} 9 \mathrm{c} 2$ cells. Pretreatment of $\mathrm{H} 9 \mathrm{c} 2$ cells with cornin blocked the reduction in expression of hypoxia-induced phosphoCREB and phospho-Akt (Figure 2B,C). To clarify the mechanism of action of cornin on hypoxia-induced reduction in expression of phospho-CREB and phospho-Akt in $\mathrm{H} 9 \mathrm{c} 2$ cells, a selective inhibitor of CREB (C646, $1 \mu \mathrm{M})$ or Akt (MK2206, $1 \mu \mathrm{M}$ ) was used. We found that pretreatment of

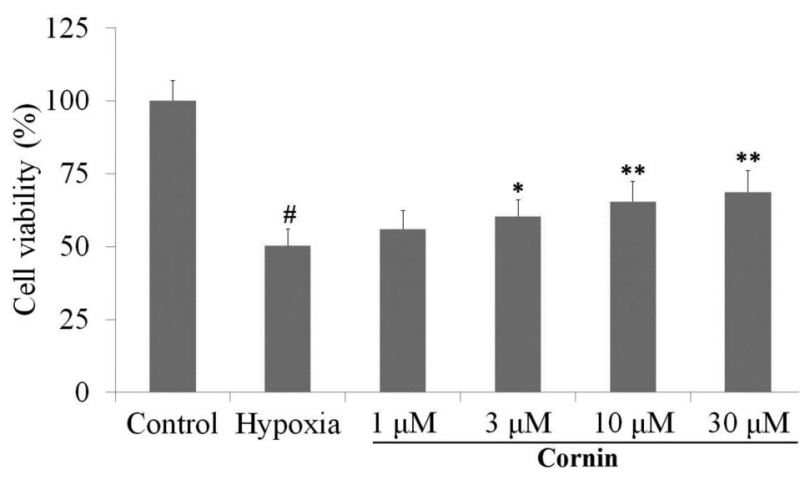

Figure 1. Protective effect of cornin against hypoxia-induced cytotoxicity in $\mathrm{H} 9 \mathrm{c} 2$ cells. $\mathrm{H} 9 \mathrm{c} 2$ cells were exposed to hypoxia for $6 \mathrm{~h}$. A hypoxic solution was bubbled with $\mathrm{N}_{2}$ for 30 min before application. Before hypoxia, cells were pretreated with cornin $(1,3,10$, and $30 \mu \mathrm{M})$ for $24 \mathrm{~h}$. Cell viability were determined by the MTT assay. Data are reported as means $\pm S D, n=6){ }^{\#} P<0.01$ compared to the control group; ${ }^{*} P<0.05$, ${ }^{* *} \mathrm{P}<0.01$ compared to the hypoxia group (one-way ANOVA followed by Dunnett's test). 
A
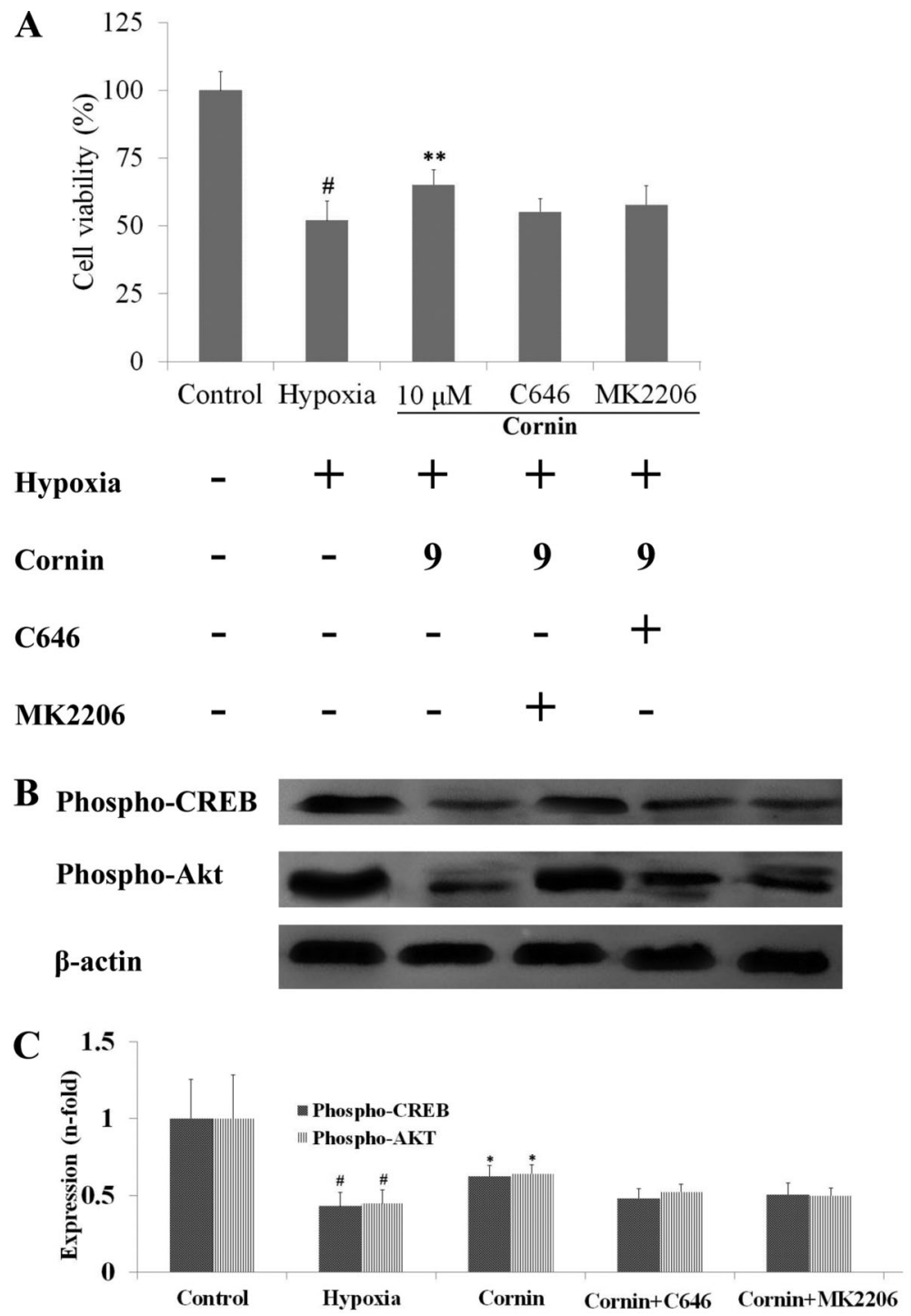

Figure 2. Effects of cornin on expression of phospho-CREB and phospho-Akt in hypoxiastimulated H9c2 cells. H9c2 cells were preincubated with cornin alone $(10 \mu \mathrm{M})$ or in addition to a selective inhibitor of CREB (C646, $1 \mu \mathrm{M})$ or Akt (MK2206, $1 \mu \mathrm{M}$ ) for $24 \mathrm{~h}$ and then exposed to hypoxia for $6 \mathrm{~h}$. Cell viability was determined by the MTT assay $(A)$. In addition, expression of phospho-CREB and phospho-Akt was analyzed by Western blotting $(B)$. In $C$, results are the foldincrease over control for $n=5$. Data are reported as means $\pm \mathrm{SD}$. ${ }^{\#} \mathrm{P}<0.01$ compared to the control group; ${ }^{*} \mathrm{P}<0.05,{ }^{* *} \mathrm{P}<0.01$ compared to the hypoxia group (one-way ANOVA followed by Dunnett's test).
$\mathrm{H} 9 \mathrm{c} 2$ cells with cornin plus C646 $(1 \mu \mathrm{M})$ or MK2206 $(1 \mu \mathrm{M})$ for $120 \mathrm{~min}$ did not attenuate the reduction of expression of hypoxia-induced phospho-CREB or phosphoAkt (Figure 2B,C).

\section{Cornin reduced myocardial infarct volume and ameliorated myocardial function}

We examined the effect of cornin on infarct size. Infarct size was reduced significantly in the cornin $30 \mathrm{mg} / \mathrm{kg}$ group compared with the vehicle-treated group (Table 1). These data strongly suggested that cornin could attenuate myocardial I/R injury.

The effect of cornin on LVSP and $\pm \mathrm{dp} / \mathrm{dtmax}$ of the left ventricle was evaluated $24 \mathrm{~h}$ and 14 days after myocardial I/R. The Heart Index was evaluated 14 days after myocardial I/R. Compared with vehicle-treated animals, rats treated with cornin had significantly improved LVSP, +dp/dtmax and - dp/dtmax $24 \mathrm{~h}$ and 14 days after myocardial I/R, and a lower Heart Index 14 days after myocardial I/R (Tables 1 and 2). These data suggested that cornin treatment provided immediate and long-term benefits for recovery of myocardial function after $\mathrm{l} / \mathrm{R}$.

\section{Cornin decreased serum levels of CK-MB and cTnT}

Serum levels of CK-MB and CTnT were elevated significantly in vehicle-treated rats subjected to I/R injury. However, treatment with cornin $(30 \mathrm{mg} / \mathrm{kg})$ reduced serum levels of CK-MB and cTnT markedly (Table 3 ).

\section{Cornin alleviated pathological injury $24 \mathrm{~h}$ after I/R}

To assess further the effect of cornin on I/R injury to the heart, we analyzed pathological changes by histology. 
Table 1. Effects of cornin ( $30 \mathrm{mg} / \mathrm{kg}$ ) on left ventricular systolic pressure (LVSP), maximal rate of rise of left ventricular pressure ( $\pm \mathrm{dp} / \mathrm{dtmax})$ and infarct volume after ischemia and reperfusion (I/R).

\begin{tabular}{lcccc}
\hline Group & LVSP $(\mathrm{mmHg})$ & $+\mathrm{dp} / \mathrm{dtmax}$ & $-\mathrm{dp} / \mathrm{dtmax}$ & Infarct volume (\%) \\
\hline Sham & $107 \pm 8$ & $10987 \pm 1387$ & $9325 \pm 941$ & - \\
Vehicle-treated & $74 \pm 9^{\#}$ & $5863 \pm 677^{\#}$ & $5795 \pm 871^{\#}$ & $35.2 \pm 8.2^{\#}$ \\
Cornin & $90 \pm 12^{*}$ & $7363 \pm 786^{*}$ & $7067 \pm 611^{*}$ & $22.5 \pm 5.4^{*}$ \\
\hline
\end{tabular}

Data are reported as means \pm SD for $n=10$ per group. At $24 \mathrm{~h}$ after I/R, LVSP, \pm dp/dtmax and infarct volume were determined. ${ }^{\#} \mathrm{P}<0.01$ compared to the sham group; ${ }^{*} \mathrm{P}<0.01$ compared to the vehicletreated group (one-way ANOVA followed by Dunnett's test).

Table 2. Effects of cornin (30 mg/kg) on left ventricular systolic pressure (LVSP), maximal rate of rise of left ventricular pressure ( $\pm \mathrm{dp} / \mathrm{dtmax})$ and the Heart Index 14 days after ischemia and reperfusion (I/R).

\begin{tabular}{lcccc}
\hline Group & LVSP $(\mathrm{mmHg})$ & + dp/dtmax & - dp/dtmax & Heart index $(100 \times \mathrm{xg} / \mathrm{g})$ \\
\hline Sham & $107 \pm 10$ & $10536 \pm 1041$ & $8912 \pm 827$ & $0.312 \pm 0.029$ \\
Vehicle-treated & $70 \pm 9^{\#}$ & $5542 \pm 722^{\#}$ & $5265 \pm 794^{\#}$ & $0.374 \pm 0.027^{\#}$ \\
Cornin & $89 \pm 11^{*}$ & $7052 \pm 931^{* *}$ & $6999 \pm 804^{\star *}$ & $0.340 \pm 0.028^{*}$ \\
\hline
\end{tabular}

Data are reported as means $\pm S D, n=10$ per group. At 14 days after $\mathrm{l} / \mathrm{R}$, LVSP and $\pm d p / d t m a x$ were determined. ${ }^{\#} \mathrm{P}<0.01$ compared to the sham group; ${ }^{*} \mathrm{P}<0.05$, ${ }^{* *} \mathrm{P}<0.01$ compared to the vehicletreated group (one-way ANOVA followed by Dunnett's test).

Twenty-four hours after I/R, the pathological features of the infarct area of vehicle-treated rats became apparent: widespread tissue necrosis, contraction bands, capillary compression, and abundant signs of hemorrhage in myocardial tissue. Upon treatment with cornin, these histological features were largely absent, and hearts appeared normal, or only minor architectural changes (interstitial edema, localized necrotic areas) were noted (Figure 3).

\section{Cornin attenuated the reduction in expression of phospho-CREB and phospho-Akt}

Western blotting was employed to measure expression of phospho-CREB and phospho-Akt in ischemic myocardial tissue. Low expression of phospho-CREB and phospho-Akt in myocardial tissues was detected after I/R,

Table 3. Effects of cornin (30 mg/kg) on serum levels of cTnT and CK-MB after ischemia and reperfusion (I/R).

\begin{tabular}{lcc}
\hline Group & $\mathrm{cTnT}(\mathrm{ng} / \mathrm{mL})$ & $\mathrm{CK}-\mathrm{MB}(\mathrm{U} / \mathrm{L})$ \\
\hline Sham & $0.20 \pm 0.03$ & $85 \pm 9$ \\
Vehicle-treated & $1.47 \pm 0.35^{\#}$ & $422 \pm 55^{\#}$ \\
Cornin & $0.85 \pm 0.22^{*}$ & $246 \pm 46^{*}$ \\
\hline
\end{tabular}

Data are reported as means $\pm S D, n=10$ per group. At $24 \mathrm{~h}$ after $\mathrm{l} / \mathrm{R}$, serum levels of troponin $\mathrm{T}$ (CTnT) and creatine kinase-MB (CK-MB) were determined. ${ }^{\#} \mathrm{P}<0.01$ compared to the sham group; * $\mathrm{P}<0.01$ compared to the vehicle-treated group (one-way ANOVA followed by Dunnett's test). but high expression was noted in the hearts of shamoperated rats (Figure 4). Cornin treatment attenuated the reduction of expression of phospho-CREB and phosphoAkt markedly.

\section{Discussion}

We demonstrated that hypoxia for $6 \mathrm{~h}$ significantly decreased cell viability (as evidenced by the MTT assay) in the culture medium. However, pretreatment with cornin $(3,10$ and $30 \mu \mathrm{M})$ decreased cytotoxicity considerably in a concentration-dependent manner.

We observed significant improvement of myocardial function in rats treated with cornin during myocardial I/R challenge as reflected by a reduction in infarct size and histopathological scores. Simultaneously, cornin stimulated cardiodynamics directly and inhibited necrosis of myocardial cells. Hence, cornin treatment provided immediate benefits for recovery of myocardial function after I/R.

Increased levels of CK-MB can be detected 3-6 $\mathrm{h}$ after the onset of chest pain in individuals who have suffered cardiac arrest. Serum levels of CK-MB peak at 12-24 $\mathrm{h}$ and return to normal within $48-72 \mathrm{~h}$. cTnT is a biomarker during myocardial damage (12), the level of which increases to a peak $12 \mathrm{~h}$ to $24 \mathrm{~h}$ during acute myocardial infarction (13). Determination of serum levels of cTnT is used in the diagnosis of ischemic heart diseases. Lowering the serum level of cTnT can lessen myocardial damage (14). Our results suggest that cornin 

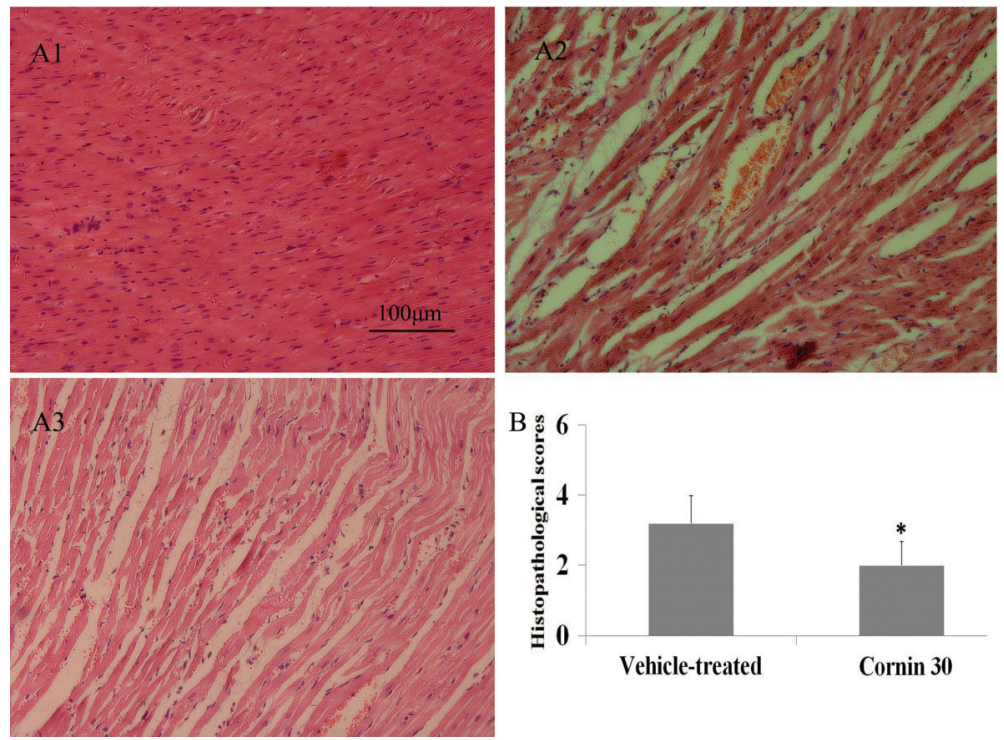

Figure 3. Effects of cornin on histopathological changes $24 \mathrm{~h}$ after ischemia and reperfusion (I/R). $A$, Effects of cornin on pathological injury. Representative light-microscopic appearance of rat myocardial morphology (hematoxylin staining; original magnification $\times 200$ ) for sham (A1), vehicle-treated (A2), and cornin $30 \mathrm{mg} / \mathrm{kg}(A 3)$ groups. B, Effects of cornin on histopathological changes. Data are reported as means $\pm S D, n=10$ per group. At $24 \mathrm{~h}$ after $\mathrm{I} / \mathrm{R}$, myocardial histopathological scores were determined. ${ }^{*} \mathrm{P}<0.01 \mathrm{compared}$ to the vehicle-treated group (sum of ranks test).

(iv) significantly reduced serum levels of cTnT and CK-MB, and that it could lessen the severity of myocardial damage.

Phospho-CREB has a key role in myocardial protection against I/R-related injury. CREB is activated by phosphorylation at Ser-133 by protein kinase $A(15,16)$, which can also be mediated by Akt (17). CREB is a substrate for various cellular kinases (including Akt) (6). Attenuation of the reduction of expression of phosphoCREB in myocardial tissue can reduce the size of the myocardial infarct (18). Increasing expression of Akt in
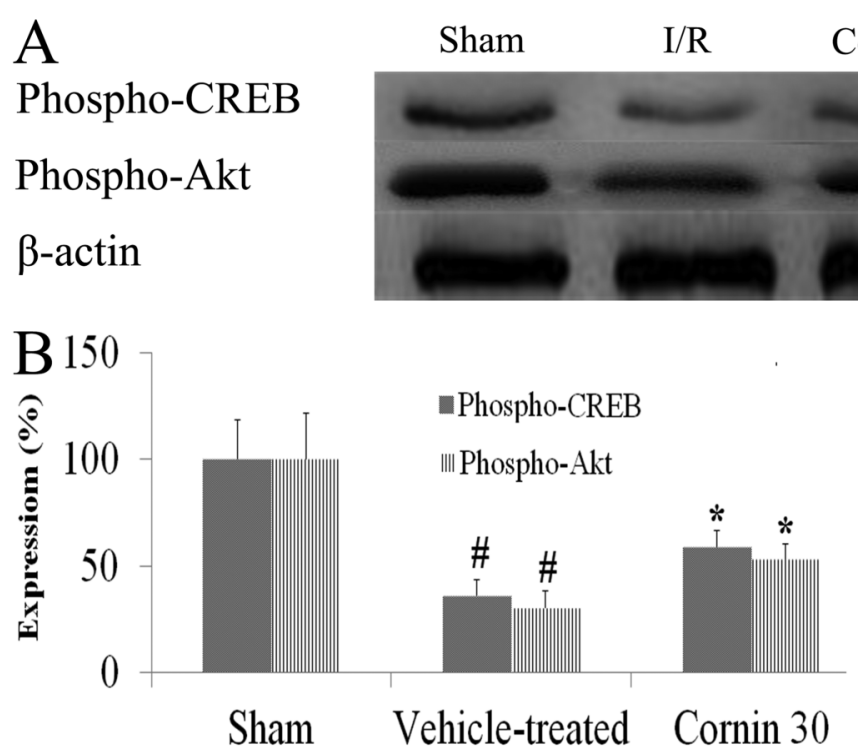

Figure 4. Effects of cornin on expression of phospho-CREB and phospho-Akt after ischemia and reperfusion (I/R). At $24 \mathrm{~h}$ after $\mathrm{I} / \mathrm{R}$ equal amounts of cell protein $(50 \mu \mathrm{g})$ were separated by SDS-PAGE and analyzed by Western blotting using specific antibodies against phospho-CREB, phospho-Akt and $\beta$-actin $(A)$. In $B$, results are the fold-increase over the sham group, $\mathrm{n}=5$. " $\mathrm{P}<0.01$ compared to the sham group; ${ }^{*} \mathrm{P}<0.01$ compared to the vehicle-treated group (one-way ANOVA followed by Dunnett's test). 
myocardial tissue can also reduce the size of the myocardial infarct, and Akt-dependent activation is dependent upon phospho-CREB (19). Our results showed that expression of phospho-CREB and phospho-Akt was reduced in vitro and in vivo. Reduced expression of phospho-Akt was dependent upon reduced expression of phospho-CREB in vitro. Hence, cornin could reduce myocardial injury during hypoxia by CREB-dependent Akt signaling.

In summary, we demonstrated that cornin can protect myocardial function in rats during myocardial $\mathrm{I} / \mathrm{R}$ injury. Cornin decreased infarct volume, improved hemodynamics, and alleviated myocardial damage. These effects of cornin were correlated with an increase in expression of

\section{References}

1. Bolli R, Becker L, Gross G, Mentzer R Jr, Balshaw D, Lathrop DA. Myocardial protection at a crossroads: the need for translation into clinical therapy. Circ Res 2004; 95: 125-134, doi: 10.1161/01.RES.0000137171.97172.d7.

2. Cannon RO III. Mechanisms, management and future directions for reperfusion injury after acute myocardial infarction. Nat Clin Pract Cardiovasc Med 2005; 2: 88-94, doi: 10.1038/ncpcardio0096.

3. Marais E, Genade S, Lochner A. CREB activation and ischaemic preconditioning. Cardiovasc Drugs Ther 2008; 22: 3-17, doi: 10.1007/s10557-007-6078-3.

4. Nagy N, Shiroto K, Malik G, Huang CK, Gaestel M, Abdellatif $M$, et al. Ischemic preconditioning involves dual cardioprotective axes with p38MAPK as upstream target. $J \mathrm{Mol}$ Cell Cardiol 2007; 42: 981-990, doi: 10.1016/j.yjmcc.2007. 02.010.

5. Li C, Tian J, Li G, Jiang W, Xing Y, Hou J, et al. Asperosaponin $\mathrm{VI}$ protects cardiac myocytes from hypoxiainduced apoptosis via activation of the PI3K/Akt and CREB pathways. Eur J Pharmacol 2010; 649: 100-107, doi: 10.1016/j.ejphar.2010.08.060.

6. Du K, Montminy M. CREB is a regulatory target for the protein kinase Akt/PKB. J Biol Chem 1998; 273: 32377-32379, doi: $10.1074 / j b c .273 .49 .32377$.

7. Jiang WL, Zhang SP, Zhu HB, Tian JW. Cornin ameliorates cerebral infarction in rats by antioxidant action and stabilization of mitochondrial function. Phytother Res 2010; 24: 547-552.

8. Kang Z, Jiang W, Luan H, Zhao F, Zhang S. Cornin induces angiogenesis through $\mathrm{PI} 3 \mathrm{~K}-A$ kt-eNOS-VEGF signaling pathway. Food Chem Toxicol 2013; 58: 340-346, doi: 10.1016/ j.fct.2013.05.017.

9. Zhang N, Pei F, Wei H, Zhang T, Yang C, Ma G, et al. Isorhamnetin protects rat ventricular myocytes from ischemia and reperfusion injury. Exp Toxicol Pathol 2011; 63: 33-38, doi: 10.1016/j.etp.2009.09.005.

10. Jiang $\mathrm{WL}, \mathrm{Fu} F H, \mathrm{Xu} B M$, Tian JW, Zhu HB, Jian $H$. Cardioprotection with forsythoside $B$ in rat myocardial ischemia-reperfusion injury: relation to inflammation response.
phospho-CREB and phospho-Akt in ischemic myocardial tissue. The main mechanism of action of cornin appeared to be modulation of CREB-dependent Akt signaling. These findings suggest the therapeutic potential of cornin against myocardial I/R injury.

\section{Acknowledgments}

This research was supported by funds from the Science and Technology Plan of Colleges and Universities in Shandong Province (number J13LM07), as well as funds from the Binzhou Medical University for Scientific Research (BY2011KYQD05), and the Natural Science Foundation of China (31170321).
Phytomedicine 2010; 17: 635-639, doi: 10.1016/j.phymed. 2009.10.017.

11. Zhu J, Qiu Y, Wang Q, Zhu Y, Hu S, Zheng L, et al. Low dose cyclophosphamide rescues myocardial function from ischemia-reperfusion in rats. Eur J Cardiothorac Surg 2008; 34: 661-666, doi: 10.1016/j.ejcts.2008.05.035.

12. $\mathrm{Wu} \mathrm{AH}$, Lane PL. Metaanalysis in clinical chemistry: validation of cardiac troponin $\mathrm{T}$ as a marker for ischemic heart diseases. Clin Chem 1995; 41: 1228-1233.

13. Mair J, Artner-Dworzak E, Lechleitner P, Smidt J, Wagner I, Dienstl $F$, et al. Cardiac troponin $T$ in diagnosis of acute myocardial infarction. Clin Chem 1991; 37: 845-852.

14. Jiang WL, Zhang SP, Zhu HB, Hou J. Cardioprotection of Asperosaponin $\mathrm{X}$ on experimental myocardial ischemia injury. Int J Cardiol 2012; 155: 430-436, doi: 10.1016/j. ijcard.2011.06.010.

15. Shaywitz AJ, Greenberg ME. CREB: a stimulus-induced transcription factor activated by a diverse array of extracellular signals. Annu Rev Biochem 1999; 68: 821-861, doi: 10.1146/annurev.biochem.68.1.821.

16. Kwak HJ, Park KM, Choi HE, Chung KS, Lim HJ, Park HY. PDE4 inhibitor, roflumilast protects cardiomyocytes against NO-induced apoptosis via activation of PKA and Epac dual pathways. Cell Signal 2008; 20: 803-814, doi: 10.1016/ j.cellsig.2007.12.011.

17. Das S, Tosaki A, Bagchi D, Maulik N, Das DK. Resveratrolmediated activation of cAMP response element-binding protein through adenosine A3 receptor by Akt-dependent and -independent pathways. J Pharmacol Exp Ther 2005; 314: 762-769, doi: 10.1124/jpet.105.084285.

18. Ye $\mathrm{Y}$, Long B, Qian J, Perez-Polo JR, Birnbaum Y. Dipyridamole with low-dose aspirin augments the infarct size-limiting effects of simvastatin. Cardiovasc Drugs Ther 2010; 24: 391-399, doi: 10.1007/s10557-010-6252-x.

19. Caravatta L, Sancilio S, di Giacomo V, Rana R, Cataldi A, Di Pietro R. PI3-K/Akt-dependent activation of cAMP-response element-binding (CREB) protein in Jurkat T leukemia cells treated with TRAIL. J Cell Physiol 2008; 214: 192-200, doi: 10.1002/jcp.21186. 